\title{
Basis for Interim Operation (BIO) for the Rework Unit (RW), Du Pont Water (DW) Plant, Moderator Processing Facility (MPF), and Technical Purification Facility (TPF)
}

by

R. E. Horne

Westinghouse Savannah River Company

Savannah River Site

Aiken, South Carolina 29808

RECEIVED

JUN 111998

asTI

This paper was prepared in connection with work done under the above contract number with the U.S. Department of Energy. By acceptance of this paper, the publisher and/or recipient acknowledges the U. S. Government's right to retain a nonexclusive, royalty-free license in and to any copyright covering this paper, along with the right to reproduce and to authorize others to reproduce all or part of the copyrighted paper.
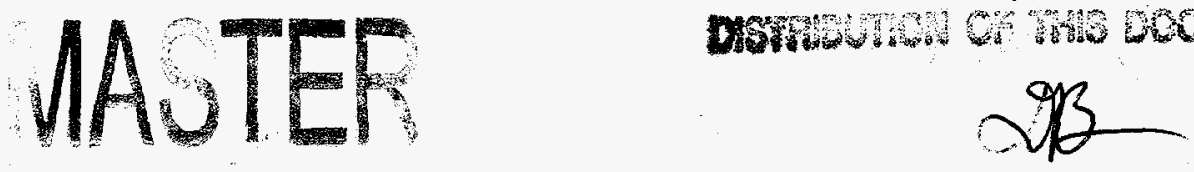


\section{BASIS FOR INTERIM OPERATION (BIO) FOR THE D AREA HEAVY WATER PROCESSING AND DRUM STORAGE FACHITIES (U)}

ISSUED: JANUARY, 1996

\section{Classification}

UNCLASSIFIED

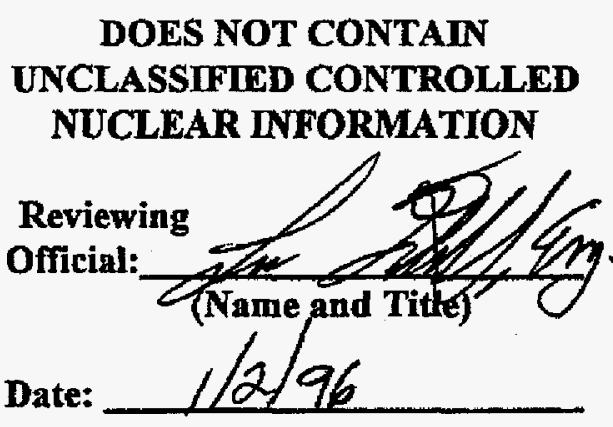

DOES NOT CONTAIN NUCLEAR INFORMATION

Patent Status

This internal management report is being transmitted without $D O E$ patent clearance, and no further dissemination or publication shall be made of the report without prior approval of the DOE-SR patent counsel.
Westinghouse Savannah River Company Engineering \& Construction Services Aiken, SC 29808

PREPARED FOR THE U.S. DEPARTMENT OF ENERGY UNDER CONTRACT NO. DE-ACO9-89SR18035

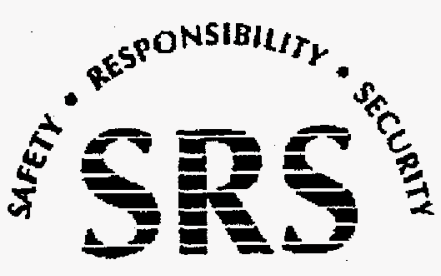

SAYANNAH RIVER SITE 


\section{DISCLAIMER}

This report was prepared as an account of work sponsored by an agency of the United States Government. Neither the United States Government nor any agency thereof, nor any of their employees, makes any warranty, express or implied, or assumes any legal liability or responsibility for the accuracy, completeness, or usefulness of any information, apparatus, product, or process disclosed, or represents that its use would not infringe privately owned rights. Reference herein to any specific commercial product, process, or service by trade name, trademark, manufacturer, or otherwise does not necessarily constitute or imply its endorsement, recommendation, or favoring by the United States Government or any agency thereof. The views and opinions of authors expressed herein do not necessarily state or reflect those of the United States Government or any agency thereof.

This report has been reproduced directly from the best available copy.

Available to DOE and DOE contractors from the Office of Scientific and Technical Information, P. O. Box 62, Oak Ridge, TN 37831; prices available from (423) 576-8401.

Available to the public from the National Technical Information Service, U. S. Department of Commerce, 5285 Port Royal Road, Springfield, VA 22161. 


\section{DISCLAIMER}

Portions of this document may be illegible electronic image products. Images are produced from the best available original document. 
WSRC-TR-94-0158, Rev. 2

KEY WORDS: Heavy Water, Radionuclide Release, Safety Analysis

RETENTION: PEBUANENT

BASIS FOR INTERIM OPERATION (BIO) FOR THE D AREA HEAVY WATER PROCESSING AND DRUM STORAGE FACILITIES (U)

ISSUED: JANUARY, 1996

Classification

UNCLASSIFTED

\section{DOES NOT CONTAN \\ UNCLASSIFIED CONTROLLED \\ NUCLEAR INFORMATION}

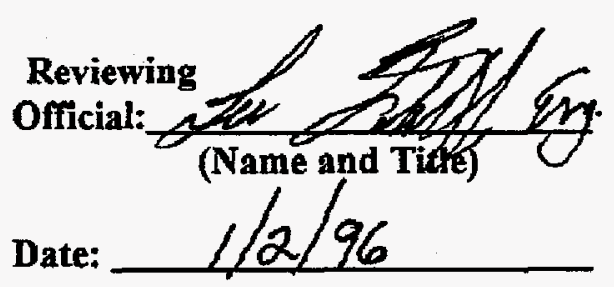

Westinghouse Savannah River Company

Engineering \& Construction Services

Aiken, SC 29808

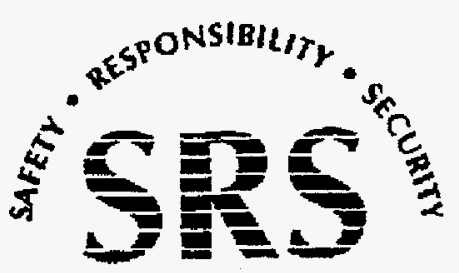

PREPAREDFOR THE U.S. DEPARTMENT OF ENERGY UNDER CONTRACT NO. DEACOS-89SR18035 
PROJECT:

DOCUMENT:

TITLE:

N/A

WSRC-TR-94-0158, Rev. 2

BASIS FOR INTERIM OPERATION (BIO) FOR THE D AREA HEAVY WATER PROCESSING AND DRUM STORAGE FACILITIES (U)

QA TASK NUMBER: N/A

REVISION NUMBER: $\quad$ N/A

\section{d.c. Lated}

T. C. EASTERLING, AUTTHOR<smiles>[C]1CCC1</smiles>

C. E. MORGAQ JF, TECHNICAL REVIEWER (TASK LEAD)

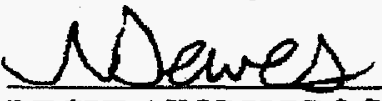

REGULATORY PROGRAMS MANAGER

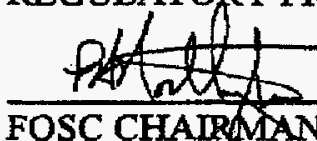

FOSC CHAIRMAN

PA +14

FACILITY MANAGER

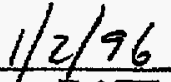

$1 \longdiv { 2 \longdiv { 9 6 } }$ DATE $1 / 3 / 96$ DATE $1 / 3 / 96$ $1 / 3 / 96$ 
WSRC-TR-94-0158, Rev. 2

Table of Contents

SECTION

PAGE NO.

1.0 INTRODUCTION

1

2.0 FACILITY DESCRIPTION

4

3.0 COMPLIANCE STATUS

10

4.0 SAFETY MANAGEMENT

11

5.0 SAFETY ENVELOPE

37

6.0 SAFETY EVALUATION

38

7.0 CONCLUSION

41

8.0 REFERENCES

42 


\section{EXECUTIVE SUMMARY}

The mission of the Heavy Water portion of D Area (or 400 Area) at SRS is to purify the site inventory of heavy water for storage in the Reactor Areas for future DOE missions. The Heavy Water portion of D Area consists of four processes that purify the heavy water to reactor grade specifications and also remove any chemical contaminants. The facilities that process the heavy water consist of the Rework Unit (RW), DuPont Water (DW) Plant, Moderator Processing Facility (MPF), and the Technical Purification Facility (TPF). The Heavy Water portion of $D$ Area also includes buildings for the storage of degraded or purified heavy water in drums. The buildings used for this drum storage are 421-D, 421$2 \mathrm{D}$, and $421-4 \mathrm{D}$.

An exemption request for DOE Order 5480.22 (TSR) and 5480.23 (SAR) has been prepared by Westinghouse Savannah River Company (WSRC) based on the low hazards expected from facility operation and drum storage and also on the limited lifetime expectancy of the heavy water facilities and storage in D Area. In order to support the exemption request, this limited scope Basis for Interim Operation (BIO) was prepared to show that an adequate level of documentation existed to ensure that the facility worker and general public are protected during normal operation and accident conditions for the Heavy Water processing and drum storage facilities. The exemption request for 5480.22 and 5480.23 will be submitted annually until the heavy water has been removed from D Area.

The three Heavy Water processing facilities in Building 420-D (RW, DW, and MPF) and Building $420-2 \mathrm{D}$ are classified as a Hazard Category 3 facility. This classification is based on the tritium content of the processes, of any drums used to charge the processes, and of the actual product drums from the processes. Building 421-2D which houses TPF and a drum storage section is classified as a Hazard Category 2 facility due to the tritium content of the drum storage portion. Buildings 421-D and 421-4D are used to store drums of heavy water and are classified as Hazard Category 2 facilities due to the tritium content of the heavy water in drums. Dose consequences for the general public, and a liquid release to the Savannah River have been shown to be of no significant impact for accidents associated with the Heavy Water processing and drum storage facilities.

The programmatic approach for worker safety is described to demonstrate its thoroughness and adequacy per the approved guidance in the following areas: Waste Management, Criticality Protection, Radiation Protection, Hazardous Material Protection, Occupational Safety and Health, Procedures and Training, Testing, Surveillance, Maintenance, Conduct of Operations, Quality Assurance, Emergency Preparedness, Fire Protection, Configuration Management, Unreviewed Safety Question (USQ), and Functional Classification.

The Technical Standards and Startup Plan have been examined to ensure the adequacy of the safety envelope, and to determine if any new requirements are necessary. 
As a result of the procedural controls placed on tritium inventory in Building 420-D (including 420-2D) and the facilities programmatic approach to safety management programs, it has been determined that the facility worker and general public are adequately protected from operation of the Heavy Water processing and drum storage facilities. Based upon the dose consequences, the accidents associated with these facilities were determined to be Class III (i.e. termed "marginal" by the BIO Guidance). 


\subsection{INTRODUCTION}

D Area at the Savannah River Site consists of four processes (i.e. facilities) that are used to purify the heavy water and remove chemical contaminants in order to meet reactor moderator specifications. The area also contains four drum storage buildings. The | facilities that are used to accomplish the process of purifying and removing chemical contaminants from the heavy water consist of the Rework Unit (RW), DuPont Water (DW) Plant, Moderator Processing Facility (MPF), and Technical Purification Facility (TPF). RW, DW, and MPF are all housed in Building 420-D, and the TPF is housed in Building $421-2 \mathrm{D}$. The buildings that are used to store heavy water in drums consist of 421-D, 421-2D, and 421-4D. For purposes of this BIO, Building 420-2D is assumed to be a part of the RW, DW, and MPF facility of Building 420-D. The drums that are in this building are used to charge the processes and to remove heavy water from the processes in Building 420-D. These drums are also included as part of the inventory of heavy water for Building 420-D.

This Basis for Interim Operation (BIO) covers the Heavy Water processing facilities and drum storage buildings of the SRS D Area. It does not cover the D Area Powerhouse or the 772-D Lab Facility. 


\subsection{REASON FOR THE BASIS FOR INTERIM OPERATION}

An exemption request for a Safety Analysis Report (SAR) and Technical Safety Requirements (TSR), as specified by Department of Energy (DOE) Orders 5480.22 (Ref. 1) and 5480.23 (Ref. 2), has been written and submitted by Westinghouse Savannah River Company (WSRC) to DOE for the Heavy Water processing and drum storage facilities. The justification for the exemption request was based on the low hazard associated with operating the facilities as well as the limited lifetime that heavy water is to remain in the area. Since the original exemption request was filed with the DOE, the Technical Standards (Ref. 3) for these facilities have been updated and a Hazard Assessment Document (HAD) per DOE Standard 1027-92 (Ref. 4) has been written for RW, DW, and MPF (Ref. 5). As a result of the DOE Standard 1027 methodology, Building 420-D (including 420-2D) has been classified as a Hazard Category 3 facility (Ref. 5). The classification of this building as Hazard Category 3 is due entirely to the amount of tritium in the heavy water. This inventory of tritium is controlled through the Technical Standards (Ref. 3). As discussed in Section 5.0 of this BIO, Building 421-2D (including TPF) is classified as a Hazard Category 2 facility, and Buildings 421-D and 421-4D have also been classified as Hazard Category 2 facilities. These categorizations, as with Building 420-D, are based on the tritium content of the heavy water. As a result of the exemption request and the limited lifetime that heavy water will remain in the area, this $\mathrm{BIO}$ is being updated in accordance with DOE guidance that requires the BIO covering a facility to be updated on an annual basis (Ref. 42). The exemption request for DOE Orders 5480.22 and 5480.23 will be submitted on an annual basis until the heavy water has been removed from $\mathrm{D}$ Area.

Since the heavy water processing and drum storage facilities have a limited time span of operation, this limited scope BIO will serve to establish an interin safety basis for the these facilities. This BIO demonstrates safety of facility workers through adherence to safety management programs. In addition to adherence to safety management programs, this BIO demonstrates safety to the public by identification of the safety envelope, and presentation of the dose consequences from postulated accidents. The BIO serves as the basis for startup and continued use of the RW, DW, MPF, and TPF units as well as drum storage in Buildings 421-D, 421-2D, and 421-4D. An approved BIO along with the Technical Standards (Ref. 3) are considered as the baseline safety documentation against which Unreviewed Safety Question Determinations (USQDs) can be made in accordance with "Nuclear Facility Unreviewed Safety Questions," Procedure 1.05 of WSRC Manual 11Q, (Ref. 7). 


\subsection{STATUS OF COMPLIANCE SCHEDULE APPROVALS}

Because the $D$ Area heavy water operations and drum storage are a part of the EFR Division facilities, the current site and EFR Order compliance status is applicable to the heavy water processing and drum storage portion of $D$ Area.

The open Compliance Schedule Approvals (CSAs) and DOE Order noncompliances for D Area involve 29 Orders. Of these, 10 were found to be relevant to $\mathrm{D}$ Area. The relevant open CSAs were mostly concerned with generic programmatic issues and do not affect the conclusions of this BIO. Reference 62 further delineates the status of DOE Orders as applied to SRS and the status of CSAs and the Exemption Requests associated with them.

The current Compliant Assessment and Implementation Report revisions for DOE Orders' 5480.22 and 5480.23 are found in Reference 63. 


\subsection{FACILITY DESCRIPTION}

The 420-D, 420-2D, 421-D, 421-2D, and 421-4D facilities are located in the D Area of the Savannah River Site (SRS). Building 420-D contains the RW, DW, and MPF processes; Building 420-2D contains the drums of heavy water to charge the processes and remove heavy water from the processes in 420-D; Building 421-D stores drum of heavy water and contains the DW plant final product processing; Building 421-2D contains the TPF process and stores drums of heavy water; and Building 421-4D stores drums of heavy water. 


\subsection{REWORK UNIT (RW)}

The Heavy Water Rework Unit (RW) (Ref. 8) is located in Building 420-D at the Savannah River Site (SRS). The RW is a continuous distillation process that concentrates degraded heavy water containing tritium greater than $15 \mu \mathrm{ci} / \mathrm{ml}$ from $1.25 \mathrm{~mol} \%$ to 99.74 $\mathrm{mol} \% \mathrm{D}_{2} \mathrm{O}$ to the reactor makeup specification of $99.75 \mathrm{~mol} \% \mathrm{D}_{2} \mathrm{O}$. This degraded heavy water is made up of miscellaneous leaks, spills, and drains from the reactor as well as heavy water from offsite sources.

The process may be considered as a continuous bubble cap distillation column with a condenser at the top and a calandria at the base. Since a single column with the required number of plates is impractical, the process is divided into five successive stages. The first stage consists of two towers, and the remaining stages have one tower each. The five stages are equipped with the necessary calandrias, condensers, and pumps to enable the six columns to be operated as an integrated unit.

Distillation is performed under vacuum to take advantage of higher relative volatility of light water to heavy water product at low pressure. Operation at reduced pressure requires fewer trays in the columns and less steam than would be required for atmospheric distillation.

In each stage, heavy water is pumped to the top of the columns and allowed to flow down over the bubble cap trays to the base of the columns. A steam-heated calandria at the base of the column produces vapor which rises through bubble caps to the top of the column. Water descending in the column becomes richer in heavy water product, and vapor rising through the column becomes weaker.

Degraded heavy water is fed to any one of the nineteen feed points on the columns or any of the tower bases. A column feed point is selected at which feed concentration comes nearest to matching the column concentration.

A vacuum is maintained in each stage by a non condensing two-stage steam ejector. The ejector draws vapor and inert gases through a water-cooled condenser, a $45^{\circ} \mathrm{F}$ cooler, and a $-17^{\circ} \mathrm{F}$ freezer where water and product in the gas are removed before being exhausted. Cooling in the freezer and coolers is provided by a dual temperature refrigeration system.

The final product in the RW process is passed through an evaporator to remove any suspended or dissolved solids before placing the product in a stainless steel drum. 


\subsection{DUPONT WATER (DW) PLANT}

The DW plant (Ref. 8) housed in 420-D is used to purify heavy water that has not been 1 contaminated (i.e. tritium concentration less than $15 \mu \mathrm{ct} / \mathrm{mi}$ ). DW has essentially the same configuration as $\mathrm{RW}$ and is processed in three stages consisting of one tower in each stage. In addition, the DW plant uses a dopp kettle and reflux column instead of an evaporator for its final product processing. 


\subsection{MODERATOR PROCESSING FACILITY (MPF)}

Various operations using heavy water may produce heavy water waste that contains high amounts of impurities, such as oil, dirt, boron, and gadolinium nitrate. These impurities must be removed from the heavy water prior to reuse to prevent the Process Water System from becoming chemically contaminated and to protect the drums during storage. The purpose of the MPF is to remove chemical contaminants from degraded heavy water so that the water may be reused or sent to the RW for further processing. The MPF is designed to remove oil, particulate matter, and any ionic impurity (with the exception of mercury) that may cause conductivity to increase. Mercury-contaminated process water cannot be charged to the MPF because mercury is highly corrosive to other metals such as the stainless steel tanks in the MPF.

The MPF (Ref. 64) receives degraded heavy water in 55-gallon drums. The heavy water is pumped from a drum to the system. The heavy water is filtered and charged through a de-emulsifier and a decanter to remove oil. Any oil removed is collected in a waste oil bottle. The water flows into a receiving tank. The MPF system pump takes a suction on the receiving tank and discharges the heavy water through three resin columns in series (with a capacity of 25 gallons each). The ion-free water from the resin columns then flows through a conductivity cell and into a 500-gallon hold tank that stores processed water. This water is then drained to the 55-gallon product drums or pumped into the RW.

The design of the 420-D system is similar to the old P Area system. The MPF is primarily located in Building 420-D with a small portion of the system located in 420-2D. The processing portion of the system, which consists of filtration, decantation, ion exchange, resin dedeuterization, and product transfer, is located north of the presently enclosed RW Pump Room and south of the Instrument Control Room in Building 420-D. The process water drums, the product drums and the associated drum charging station are located in 420-2D. 


\subsection{TECHNICAL PURIFICATION FACILITY (TPF)}

The TPF (Ref. 9) is located in Building 421-2D. The purpose of the process is to remove mercury from degraded heavy water. TPF is used to process heavy water that contains greater than 0.01 parts per million (ppm) of mercury. TPF can also remove other heavy metals such as lead, chromium, and cobalt. This is accomplished by prefiltering the heavy water feed with a modular filtering assembly on a cart while it is being charged to the system. If advised by Engineering and the Facility Manager, potassium permanganate may be added on a case basis after prefiltering to neutralize organic material in the feed and provide added assurance that organics will not damage the resin. Next, the contaminated heavy water is circulated through a resin column filled with Duolite GT-73 type resin at ambient temperature. The TPF can process a maximum of one 55-gallon drum of heavy water at a time. Low pressure ( $\approx 10 \mathrm{psig})$, low flow pumps $(0.2-1.0 \mathrm{gpm})$ are used for charging and recirculation. Feed drums sometimes contain a layer of contaminated sediment. During normal operation, the charging step siphons off clear heavy water only. Sediment is not processed by the TPF. Sediment is collected in a single 55-gallon drum and transferred out of the process. If sediment is accidentally introduced into the process, in-line filters remove the sediment. Processing does not stop unless the $\Delta \mathrm{P}$ across the filters requires it. Recirculation of clear heavy water continues until its mercury concentration is less than or equal to $0.01 \mathrm{ppm}$. Subsequently the treated heavy water is transferred to a clean 55-gallon drum for storage or further processing at another location. 


\subsection{DRUM STORAGE}

Drums of heavy water are stored in D Area in Buildings 421-D, 421-2D, and 421-4D. The drums are stored in these buildings in stacks of up to three high. The buildings used to store drums of heavy water are primarily constructed of transite walls and roofs with steel frames. The flooring is concrete with containment curbing to prevent any spilled moderator from exiting the building. Containment ramps are provided for personnel and equipment entering the building, and climate control consists of a general exhaust and steam heater system (Ref. 43). 


\subsection{COMPLIANCE STATUS}

The current site and Department of Energy (DOE) Order compliance status is applicable to the heavy water processing and drum storage operations in D Area.

The Savannah River Site (SRS) has an extensive DOE Order compliance program. This plan consists of the following:

- The evaluation of Level I Environmental Safety and Health (ES\&H) DOE Orders

- The review of outstanding Compliance Schedule Approvals (CSAs) and newly determined noncompliances and deficiencies

- The preparation of CSAs and Exemption Requests for the current conditions of the heavy water processing and drum storage facilities

- Long-term action to prepare additional CSAs and Exemption Requests for future conditions of the facility (i.e., all processing complete and heavy water moved to another onsite location)

Therefore, the program for resolving the noncompliances for the heavy water processing and drum storage in D Area is a part of a larger program. Reference 62 further delineates the status of DOE Orders as applied to SRS and the status of CSAs and Exemption Requests associated with them as applied to the EFR Division.

The current status of the heavy water processing and drum storage in D Area with respect to DOE Orders 5480.22 and 5480.23 can be found in Reference 63. 


\subsection{SAFETY MANAGEMENT}

The expected hazards to the facility workers from RW, DW, MPF, and TPF operation and heavy water drum storage in D Area include exposure to tritium or other radionuclides contained in the heavy water, steam, and routine industrial hazards.

Facility safety on a day-to-day basis requires the implementation of a safety management program in order to achieve the following:

- Adequate level of facility worker safety from routine industrial hazards

- Adequate level of facility worker and public safety from normal operational releases and exposures

- Adequate level of public safety from postulated accidental releases of hazardous material

The SRS Safety Management Program covers a broad spectrum of issues, from hazardous identification and assessment to hazard control during design and operations, in order to enhance worker and public safety.

The objectives of safety management are accomplished through the implementation of the following programs per approved guidance, which are described in the following sections:

- Waste Management

- Criticality Protection

- Radiation Protection

- Hazardous Material Protection

- Occupational Safety \& Health

- Testing

- Surveillance

- Configuration Management

- Functional Classification
- Maintenance

- Conduct of Operations

- Quality Assurance

- Decontamination \& Decommissioning

- Procedures and Training

- Emergency Preparedness

- Fire Protection

- Unreviewed Safety Question 


\subsection{WASTE MANAGEMENT}

Radioactive waste management refers to the capabilities at SRS to control, collect, handle, and dispose of liquid, gaseous, and solid wastes that may contain radioactive material during normal operations including anticipated operational occurrences.

A study of the waste management practices at SRS, including the environmental effects of chronic radionuclide releases, has been documented (Ref. 10). This study is supplemented annually through publication of the results of environmental monitoring. Application of known meteorological and other dispersion and dosiometric parameters to SRS releases of radioactive material shows that the maximum radiation exposure to an individual at the site boundary caused by SRS atmospheric releases is approximately 0.2 percent of the radiation exposure received by this population from natural sources.

The types of waste expected from operations of the Heavy Water processing facilities include waste rags, solvent rags, waste oil, resin from MPF and TPF, potassium permanganate, sediment, and waste associated with the drum wash process. Waste rags, solvent rags, waste oil, and sediment are collected in a satellite area and removed by the waste management group. The resin from MPF and TPF are sent to the Solid Waste Facility, and the potassium permanganate is sent to the process sewer. Any contaminated waste generated from the processes or drum storage are controlled by procedure. 


\subsection{CRITICALITY PROTECTION}

Criticality protection is not applicable because fissile material is not handled or stored in the Heavy Water facilities. 


\subsection{RADIATION PROTECTION}

The Radiation Protection Program is conducted in compliance with WSRC Procedure Manual 5Q (Ref. 17) so that exposure of WSRC employees, subcontractors, visitors, and the general public to radiological hazards is well below DOE limits and are As Low As Reasonably Achievable (ALARA). The following topics will be discussed in this section as provided in WSRC Procedure Manual 5Q:

- alara

- External Radiation Exposure Control

- External Dosimetry

- Internal Radiation Exposure Control

- Internal Dosimetry

- Radiological Protection Instrumentation Programs

- Respiratory Protection Program

- Air Monitoring

- Radiological Monitoring and Contamination Control

- Radiological Protection Record Keeping

- Radiological Area Boundaries, Posting, and Controls

- Radiological Protection Training

- Entry and Exit Control Program

\section{AS LOW AS REASONABLY ACHEVABLE}

The radiation protection controls applied at SRS ensure that all radiation exposures are maintained ALARA and do not exceed applicable limits. The SRS ALARA policy and program are provided in the WSRC Policy Manual 1-01 (Ref. 11) and are implemented through WSRC-IM-90-140 (Ref. 13). 


\section{EXTERNAL RADIATION EXPOSURE CONTROL}

External radiation exposure control is accomplished by establishing administrative dose control levels well below DOE regulatory dose limits, by monitoring personnel for external radiation exposure, by tracking exposures received, and by identifying and controlling radiation sources. To maintain personnel radiation exposure well below regulatory limits, administrative control levels are established to help reduce individual and collective radiation dose. WSRC Procedure Manual 5Q (Ref. 17) establishes practices for the conduct of radiological control activities at SRS.

\section{EXTERNAL DOSIMETRY}

A dosimetry program was established at SRS to ensure that radiation and contamination control programs are adequately protecting workers and visitors. All activities associated with the External Dosimetry Program are maintained in compliance with DOE requirements by Health Physics Technology. The External Dosimetry Technical Basis Manual (Ref. 16) provides the technical basis for the External Dosimetry Program, including measures to ensure the validity and quality of external dosimetry results.

\section{INTERNAL RADIATION EXPOSURE CONTROL}

Internal radiation exposure control at SRS is accomplished by establishing administrative control levels, identifying and controlling sources or potential sources of airborne radioactivity, maximizing the use of engineered controls, the application of respiratory protection where appropriate, and monitoring workers for internal radioactivity (Ref. 17).

\section{INTERNAL DOSIMETRY}

Internal dosimetry at SRS is accomplished by in-vivo and in-vitro bioassay and subsequent dose assessment. The methods and frequency of the bioassays and dose assessments are given in the Internal Dosimetry Technical Basis Manual (Ref. 18).

\section{RADIOLOGICAL PROTECTION INSTRUMENTATION PROGRAMS}

Radiological protection equipment and instrumentation are selected, examined, and tested in accordance with the WSRC 5Q1.2 Manual (Ref. 58) and WSRC Q2 Manual (Ref. 59). The specific types of instrumentation and their initial placement are the responsibility of Health Physics Technology. Fixed instruments such as area radiation monitors and constant air monitors are provided to characterize the workplace as required by DOE Order 5480.11 (Ref. 14). 


\section{RESPIRATORY PROTECTION PROGRAM}

It is the WSRC policy to protect employees from exposure to airborne radioactive contaminants. The Respiratory Protection Program is one method of protection. The Industrial Safety and Hygiene Section Manager has overall responsibility and authority for the Respiratory Protection Program. WSRC 4Q1.6 Manual (Ref. 60) discusses the criteria for selection of respiratory equipment.

\section{AIR MONITORING}

Air monitoring equipment includes portable and fixed air sampling equipment and continuous air monitors. This equipment is used in situations where airborne radioactivity levels can fluctuate and early detection of airborne radioactivity could prevent or minimize inhalation of radioactivity by personnel. Air monitoring equipment is selected, examined, and tested in accordance with the WSRC 5Q Manual (Ref. 17).

\section{RADIOLOGICAL MONITORING AND CONTAMINATION CONTROL}

Radiological Control and Health Physics (RC\&HP) personnel perform radiation and contamination surveys of given locations in a facility to determine existing conditions in accordance with WSRC 5Q1.2 Manual (Ref. 58). Information provided by these surveys are used for determining personnel stay time, area postings, and other radiological work planning.

\section{RADIOLOGICAL PROTECTION RECORD KEEPING}

It is the WSRC policy that all radiological exposures are recorded for personnel at SRS. These records provide employees and management with knowledge of radiological exposures and are needed to demonstrate the effectiveness of the Radiation Protection Program. The WSRC 5Q and Q1-1 Manuals (Refs. 17 and 15) contain the prescribed practices for preparing and retaining the radiological related records.

\section{RADIOLOGICAL AREA BOUNDARIES, POSTING, AND CONTROLS}

Radiological posting is used to alert personnel to the presence of radiation and radioactive materials to aid them in minimizing exposures and preventing the spread of contamination. WSRC 5Q Manual (Ref. 17) provides the general posting requirements. 


\section{RADIOLOGICAL PROTECTION TRAINING}

Education and training of employees are essential to the success of radiation exposure reduction. WSRC 5Q Manual (Ref. 17) delineates the appropriate level of radiological training, as well as the requirements for and the frequency of training.

\section{ENTRY AND EXIT CONTROL PROGRAM}

Access to radiologically posted areas is controlled to minimize radiation exposure, the spread of radiological contamination, and personnel contamination. WSRC 5Q Manual (Ref. 17) delineates entry and exit requirements for controlled areas. 


\subsection{HAZARDOUS MATERIAL PROTECTION}

SRS complies with the applicable requirements for control of personnel exposure to hazardous materials; however, there are no significant amounts of hazardous chemicals/materials used, stored, or allowed in Buildings 420-D, 420-2D, 421-D, 421-2D, and $421-4 \mathrm{D}$ which could adversely affect the health and safety of the public or pose a reasonable risk to workers.

All employees involved with the Heavy Water processing facilities receive annual Resource Conservation and Recovery Act (RCRA) and Occupational Safety and Health Administration (OSHA) training covering hazardous material protection. In addition to this, the facilities and general area are assessed by the Reactor Environmental Group in order to ensure compliance with the hazardous material protection portions of WSRC Procedure Manuals $4 \mathrm{Q}$ and $20 \mathrm{Q}$ (Refs. 46 and 45 ).

Material Safety Data Sheets (MSDS) are available for all chemicals used in the Heavy Water processing facilities and the chemicals are tracked through procedure RDP 14.01 (Ref. 65). Any material that is deemed hazardous to the facility worker or the public will be handled by procedures that meet the requirements of WSRC Manual 20Q (Ref. 45). 


\subsection{OCCUPATIONAL SAFETY AND HEALTH}

The occupational safety and health of the facility workers is carried out through the Industrial Safety and Hygiene Program. The goals of the Industrial Safety and Hygiene Program are to provide a hazard free work environment. This program is accomplished by reviewing work packages, procedures, and operations which may involve worker exposure to chemicals, biological, or physical hazards. After determination of a hazard to the facility worker, the program assures that the hazard is either minimized or eliminated.

Implementation of safety requirements in WSRC Procedure Manuals $2 \mathrm{Q}, 4 \mathrm{Q}$, and $8 \mathrm{Q}$ (Refs. 48, 46 and 31 ) is achieved through training and facility worker commitments. Specific training programs such as Hazardous Energy Control (Lockout/Tagout); Basic. Hazards Communication; and Occupant Fire Safety are provided to facility workers on an annual basis. In addition, each employee is advised annually through the personal development process or a safety commitment letter that obeying safety rules and working safely are a condition of employment. Similarly, as a result of the direction provided in WSRC 8Q manual, WSRC safety engineers conduct an annual safety assessment of all the facilities at SRS.

Any time that a modification is made to the facility, a safety review per Procedure 51 of WSRC Manual $8 Q$ (Ref. 31) is performed.

Life safety and fire safety walkdowns are performed in the Heavy Water facilities in accordance with Procedure DMP 4.05 of Excess Facilities and Reactor Fuel Storage Program Division Manual RD 4.1 (Ref. 40). This procedure serves to inspect facilities on a monthly basis in order to identify and correct life safety deficiencies within the Excess Facilities and Reactor Fuel Storage Program Division. Each finding is reported to the appropriate manager and tracked for resolution of the concern. 


\subsection{PROCEDURES AND TRAINING}

\subsubsection{SITE PROCEDURES}

Site procedures have been developed to ensure that routine, off-normal, and emergency activities are conducted in a safe manner. Heavy Water operations, maintenance, and administrative procedures are written to guide the applicable activities. The procedures are prepared, reviewed, and approved in accordance with written guides and governing quality assurance and administrative procedures. These procedures are designed to be used by the operating organization to ensure that the limits in the Technical Standards (Ref. 3) are not exceeded.

\subsubsection{Administrative Procedures}

SRS administrative procedures specify the policies, practices, requirements, and instructions necessary for site personnel regarding general site operation. The procedures govern changes to procedures, conduct of operations, personnel training, and changes to systems or equipment that affect safety. This ensures that activities are consistently performed in a way that has been reviewed and approved by independent oversight groups. The administrative procedures include, but are not limited to, the following:

- SRS Conduct of Operations, WSRC Procedure Manual 2S

- Excess Facilities and Reactor Fuel Storage Program Division Administrative Manual, WSRC Procedure Manual RD-1

- Reactor Quality Assurance and Assessment Department Administrative Manual, WSRC Procedure Manual RD 8.1

- Maintenance Administrative Procedures, WSRC Procedure Manual 1Y

- Quality Assurance Manual, WSRC Procedure Manual 1Q

- Reactor Engineering Department Administrative Manual, WSRC Procedure Manual R5.1

- Startup Test Manual, WSRC Procedure Manual SE

- Employee Safety, WSRC Procedure Manual $8 Q$

- Conduct of Engineering and Technical Support, WSRC Procedure Manual E7 
- Administrative \& Procedural Controls System for Reactor and Nonreactor Eacilities, WSRC Procedure Manual $11 Q$

- Industrial Hygiene Manual, WSRC Procedure Manual 4Q

\subsubsection{Operating Procedures}

Operations, including abnormal conditions, are controlled by detailed operating procedures as described in Reference 19. Operating procedures are approved before use and are prepared to maintain normal operation within the requirements of Technical Standards (Ref. 3), Abnormal Response Procedures (ARP) and Abnormal Operating I Procedures (AOP) specify actions to be taken to place the facility in a safe condition during unusual situations. These emergency procedures specify measures to be taken in evacuating the facilities and are compatible with emergency and disaster plans developed for the overall site. Operating, ARP, and AOP procedures are assigned a numerical code for identification. The code defines the building with which the procedure is associated and identifies the system and function for which the procedure is used. All major system operating procedures for $\mathrm{RW}, \mathrm{DW}, \mathrm{MPF}$, and TPF have been revised in accordance to WSRC-IM-90-I36 (Ref. 20). The remaining procedures will be reviewed and updated on an as needed basis.

\subsubsection{Maintenance Procedures}

Maintenance procedures maintain equipment at the required quality level to perform its intended function. These procedures include provisions for repair or replacement of equipment at the time of failure. Maintenance includes both preventative and corrective maintenance. Heavy Water Operations Department authorizes maintenance work and determines if the work has been completed satisfactorily.

Facility support is used by Heavy Water Operations in the Heavy Water facilities to perform all necessary maintenance activities. The work control system is governed by WSRC Manuals $1 Q$ and $1 Y$ (Refs. 22 and 44).

\subsubsection{TRAINING}

The SRS Staff Training Program has been developed and implemented to ensure the following:

- Personnel are effectively trained and qualified to safely operate and maintain the site throughout its designed life.

- Changes are adequately understood and accepted by the operating staff, and resulting problems or deficiencies are properly dispositioned. 
The Operating and Maintenance Training Program has been developed and implemented based on DOE Orders 5480.18 and 5480.6 (Refs. 23 and 24); American National Standards Institute/American Nuclear Society (ANSU/ANS) 3.1-1981 (Ref. 25); NUREG00737 (Ref. 26); and Institute of Nuclear Power Operations (INPO) training guidelines.

Heavy Water Operators are qualified in accordance with DOE Order 5480.20A (Ref. 27). The qualification is carried out by formal classroom instruction, computer assisted instruction, and on-the-job training through initial training, continual training, and retraining. Initial qualification of Heavy Water Operators depends on satisfactory completion of a comprehensive written, oral, and operating examination, satisfactory physical condition, general health, and high supervisory judgment of general qualifications. Continuing training will be based on those items specified in the Startup Plan (Ref. 28). 


\subsection{TESTING}

The Department of Energy (DOE) and Westinghouse Savannah River Company (WSRC) recognize the need for testing. WSRC has committed to ensuring adequate review and approval of the test requirements and procedures used to conduct testing as well as administrative controls used to control testing in the field. Testing will be controlled by formalized requirements using previously approved operating, surveillance, and special test procedures. Heavy Water Operations will be required to authorize testing of newiy installed equipment. In addition, testing for all startup activities will be conducted within the requirements of WSRC manual SE (Ref. 29). 


\subsection{SURVEILLANCE}

Heavy Water surveillance activities have been evaluated in the areas of Operations, Environmental Regulatory, Best Management Practices, and Industrial Safety. These surveillance activities are either identified in the Startup Plan (Ref. 28), Technical Standards (Ref. 3), or operating procedures. The planned surveillances related to the processes and drum storage are as follows:

Operations

- Periodic inventory of 420-D (including 420-2D) curie content

- Periodic inspection of building temperatures during cold weather

- Periodic inspection of the Kanne monitoring systems

\section{Environmental Regulatory}

- Inspection of all staging areas for RCRA compliance

- Inventory of Material Safety Data Sheets for chemicals present

- Inspection of effluent releases to remain within discharge EPA limits

\section{Best Management Practices}

- Checks on satellite accumulation areas to ensure RCRA compliance

- Walk down areas for general regulatory compliance

- Surveiltances of personnel training records for compliance with the Spill Prevention Control and Countermeasure Plan and the Best Management Practices Plan, required by the Clean Water Act.

- Surveillance of personnel for compliance with RCRA

\section{Industrial Safety}

- General building walk through

- Combustible, explosive, and hazardous material control

- Lifting and handling equipment

- Emergency lighting

This list of surveillances is a representative sample of the surveillances that will be performed as part of facility operations. 


\subsection{MAINTENANCE}

Maintenance has a primary tole in assuring safe and reliable plant operation. To carry out this role a strong maintenance philosophy and culture have been developed. The basis for a strong maintenance plan contains the following elements:

1. Maintenance Department Organization and Administration

2. Training and Qualification of Maintenance Personnel

3. Maintenance Facilities

4. Corrective, Predictive, and Preventative Maintenance

5. Maintenance Procedures

6. Planning, Scheduling, and Coordinating Maintenance

7. Control of Maintenance Activities

8. Post-Maintenance Testing

9. Procurement of Parts, Materials, and Service

10. Material, Receipt, Storage, Inspection, and Handling

11. Control and Calibration of Measuring and Test Equipment

12. Maintenance Tools and Equipment Control

13. Station Material Condition Inspection

14. Management Involvement

15. Maintenance Fistory

16. Analyses of Maintenance Problems

Maintenance in the Heavy Water facilities is administered through WSRC Procedure Manual 1Y, Maintenance Administrative Procedures (Ref. 44), and WSRC Procedure Manual 1Q, Quality Assurance Manual (Ref. 22). 


\subsection{CONDUCT OF OPERATIONS}

Westinghouse Savannah River Company (WSRC) of Westinghouse Electric Corporation operates SRS for the U.S. Department of Energy (DOE) under Contract DE-AC-0989SR18035. Wackenhut Services, Inc. (WSI) provides protective services for SRS under direct contract to DOE. The Heavy Water facilities in the D Area will be operated by WSRC with oversight by the DOE-SR (Savannah River).

WSRC is a full scope, self sufficient, site management and operation organization designed to accomplish the DOE-SR production and waste management missions efficiently and cost-effectively while ensuring safe, secure, and environmentally sound operations.

The President of WSRC reports to the Executive Office of Westinghouse Electric Corporation. This placement of WSRC within the corporate reporting structure indicates the high priority given to SRS and ensures management attention at the highest level of the corporation. Westinghouse has assigned a single, onsite executive, the WSRC President, the responsibility and accountability for managing WSRC. All personnel within WSRC who are required for regular day-to-day effort in connection with SRS management and the operating contract are located at or near the site.

\section{SITEWIDE CONDUCT OF OPERATIONS}

Conduct of operations procedures have been implemented at SRS through WSRC Procedure Manual 2S, Conduct of Operations (Ref. 30). The manual contains a very detailed and comprehensive organization including diagrams, duties, and responsibilities with interfaces specified in the following areas:

\section{- Shift Turnover}

A formal shift turnover program ensures each operator and supervisor is provided the knowledge required to adequately and safely discharge the responsibilities of the shift position or assignment. The shift turnover checklist identifies a number of items and conditions appropriate for shift turnover. These include system status, logs, instructions to be reviewed, explanation of all abnormalities/alarms/annunciators, and changes in radiological status. The oncoming shift personnel have read and signed the applicable shift turnover check sheets.

- Lockouts

Lockouts are used to control equipment by removing equipment from service or by returning off-line equipment to service. 
Lockouts protect workers and equipment during maintenance activities. WSRC Manual $8 Q$ (Ref. 31) provides the means of writing instructions for the isolation and restoration of equipment and systems to ensure the safety of personnel and equipment during maintenance, modification, inspection, and testing activities.

- Notification/Reporting

Events requiring notification of offsite personnel and/or regulatory agencies can occur frequently. Information has to be granted and transmitted with a consistent, systematic, and controlled method in accordance with DOE Orders and national security requirements. DOE Order 5000.3B (Ref. 32) lists the requirements for occurrence reporting and processing. At SRS, these requirements are addressed in WSRC Manual 9B, "Site Item Reportability and Issues Management (SIRIM)" (Ref. 33).

- Control of Equipment and Systems

The operating shift must be aware of how equipment and systems will function for operational purposes. The Shift Technical Coordinator is responsible for status control of all systems as required by Reference 30 . The Shift Technical Coordinator shall maintain the system's status files in the control room. Shift Technical Coordinators are also required to log changes in system status in the system status files. Reference 30 addresses the actions necessary to restore equipment to service after maintenance activities.

- Independent Verification

The function of an independent verification program is to verify that site systems and equipment critical to safe operation are configured as intended. Reference 30 establishes guidelines for implementing an independent verification program within an organization. It also includes the qualifications required for individuals assigned to perform independent verification.

- Control of Operating Procedures

Reference 30 requires that all activities shall be performed in accordance with approved procedures. QAP 5-1, "Instruction, Procedures and Drawings," of WSRC Quality Assurance Manual 1Q (Ref. 22) specifies that activities affecting quality shall be prescribed by and performed in accordance with documented 
procedures. MRP 3.27, "Management of Division and Department Level Procedures," of WSRC Procedure Manual 1B (Ref. 34) and Excess Facilities and Reactor Fuel Storage Program Division Administrative Manual (Ref. 7) Procedure 7.02 specify the requirements that must be met in preparing, revising, and approving procedures.

As a result of the restart of the D Area Heavy Water processing facilities, the Excess Facilities and Reactor Fuel Storage Program Division Senior Management requested an interdivisional self assessment be conducted of the facilities for compliance with Conduct of Operations. This assessment evaluated fifteen topics based on WSRC Manual 2S (Ref. 30). As a result of this assessment, fifty-seven intermediate recommendations and twentyfour long term recommendations for implementing a formal Conduct of Operations. Program were identified. These recommendations are documented in RRD-RES-930128 (Ref. 35). All intermediate recommendations were addressed prior to restart, and all long term recommendations are being addressed on an as needed basis. 


\subsection{QUALITY ASSURANCE}

The WSRC quality assurance program is implemented within the Excess Facilities and Reactor Fuel Storage Program Division on a graded basis as described in the WSRC Policy Manual (WSRC-1-01) (Ref. 36), "WSRC Quality Assurance Management Plan," (Ref. 37) and the WSRC Quality Assurance Manual (WSRC 1Q) (Ref. 22). Activities affecting quality, safety and/or reliability of Excess Facilities and Reactor Fuel Storage Program Division operations products and services are performed in accordance with documented and approved procedures appropriate for the task to be performed. Procedures are used to ensure that quality assurance requirements are planned and systematically implemented as part of the activities performance. The quality assurance program provides for the indoctrination and training of personnel, as necessary, to ensure that suitable proficiency is achieved and maintained (Ref. 22).

Personnel who perform quality verification activities within the Excess Facilities and Reactor Fuel Storage Program Division are qualified and/or certified, as appropriate, based on the requirements of the WSRC Quality Assurance Manual. Qualifications/certification programs include documentation of capability through either written tests and/or physical demonstrations of skill and continued maintenance of the individual's proficiency based upon retraining or continued satisfactory performance (Ref. 22). 
WSRC-TR-94-0158, Rev. 2 4.12 DECONTAMTNATION AND DECOMMISSIONING

Because the Heavy Water facilities in D Area will be in operation, this section is not I applicable. 


\subsection{EMERGENCY PREPAREDNESS}

A Site Emergency Plan (Ref. 39) has been developed and implemented at SRS. This plan includes the following:

- A description of the response organization, authorities, responsibilities, and relationship with the SRS Technical Support Center (TSC)/Emergency Operations Facility (EOF) established for responding to an emergency situation that may arise

- A description of emergency classification system and associated Emergency Action Levels (EALs)

- The plans and procedures to be followed

- The staffing and training needs of the emergency response organization

- The facilities, equipment, and resource requirements

- Emergency assessment and notification procedures

- Personnel protection procedures

- Criteria for how the effectiveness and readiness of emergency operations will be determined

- Interfaces with the overall SRS Program

- Provisions for notification and activation of reactor emergency response team

- Technical assessment and mitigation of facility emergency conditions

- Media/Public information

The SRS Emergency Plan (Ref. 39) and the Management and Requirement Procedure (MRP) 4.08, "Events, Conditions, and Concerns Determination," of WSRC Procedure Manual 1B (Ref. 34), satisfy the requirements contained in the DOE 5500 Series Orders.

The Emergency Management (EM) Hazards Assessment for D Area has been completed (Ref. 56) to comply with part of the SRS Emergency Plan. However, an approved and implemented Emergency Preparedness Program covering the heavy water operations and drum storage is not in compliance with the site level guidance. As a result of this, the EFR Division is in the process of developing a plan to come into compliance with the SRS 
Emergency Plan. Once completed, the Emergency Preparedness program for the heavy water processing and drum storage in D Area will be reflected in the annual update of this BIO. 


\subsection{FIRE PROTECTION}

Fire protection walkdowns are performed in the Heavy Water facilities in accordance with Procedure Manual RD 4.1 (Ref. 40). These are performed by the Excess Facilities and Reactor Fuel Storage Program Division Fire Protection Coordinator to ensure compliance with site policies and DOE orders. The walkdowns serve to identify and correct any fire safety deficiencies located within Excess Facilities and Reactor Fuel Storage Program Division facilities on a monthly basis. The fire protection coordinator reports all findings to the responsible manager for corrections. All findings are tracked and controlled by the fire protection coordinator. Fire control and planning for the Heavy Water processing facilities is carried out through Manual 2Q2-4-D (Ref. 47). This is accomplished by having the Fire Protection Coordinator work with the Site Fire Department in developing. preplans and having the D Area fire brigade participate in fire drills with the Site Fire Department. Fire drills are performed at least annually. The Site Fire Department also does a quarterly inspection of all facilities that includes a complete facility inspection for fire safety. In addition to this, all fire fighting equipment is inspected on an annual basis.

Fire Hazards Analyses (FHAs) have been prepared for Buildings 420-D and 421-D (Refs. 54 and 55). Fire protection systems consist of portable fire extinguishers, a fire hydrant and hose located next to Building 420-D, and manual fire alarm pull boxes. The only applicable fire permits that are used in the Heavy Water facilities are flame and spark permits (Ref. 57). 


\subsection{CONFIGURATION MANAGEMENT}

A Configuration Control Program, as described in Procedure Manual 7E, Configuration Management Manual (Ref. 50) and the WSRC 1E (11/15/94) Manual (Ref. 51) is established to:

- Identify and document the technical baseline of safety related structures, systems, components, and computer software

- Ensure that changes to the technical baseline are properly developed, assessed, approved, issued, and implemented through the use of the following:

- Change Control Review Boards

- Setpoint Control

- Design Control

- Software Control

- Technical review and approval process, including performance of a USQ screening/evaluation and review of environmental documentation

- Document Control

- Verification and acceptance process

- Compliance auditing

- Maintain a system for recording, safeguarding, and indicating the status of technical baseline documentation.

The heavy water processing and drum storage facilities in D Area do not contain all of the applicable requirements of a Configuration Management Program (Ref. 50). However, a graded approach to Configuration Management is being implemented based upon the facility hazards and the limited expected operating lifetime. 


\subsection{UNREVIEWED SAFETY QUESTION (USQ)}

The unreviewed safety question determination (USQD) process at SRS is required by DOE Order 5480.21 (Ref. 49) and is govemed at the site level by following the guidance given in the WSRC 11Q Manual (Ref. 12). The implementing procedure for the Excess Facilities and Reactor Fuels Storage Program Division (EFR) is Procedure 1.05 of WSRC Manual 11Q (Ref. 7). Proposed activities, such as facility modifications, equipment modifications, operating procedure revisions which change the operational steps or intent of the procedure, other activities that could effect safe operation of the facility and potential inadequacies (analytical errors or omissions) in the facility safety analysis, are evaluated by the USQD process. The USQD process determines if the proposed activity or potential inadequacy is within the current DOE approved facility safety envelope and the risk (product of frequency and consequences) associated with the proposed activity is within the DOE accepted facility risk. The proposed activity must be approved by DOE and the Authorization Basis updated if an unreviewed safety question (USQ) evaluation indicates that a USQ is invoived with the activity. If no USQ is involved, WSRC implements the activity without DOE approval and the Authorization Basis is updated to reflect the proposed activity in the annual BIO update. Guidelines for determining if a USQ exists, based on changes in frequency and consequence of accidents, are contained in WSRC 11Q Manual Ref 12. 


\subsection{FUNCTIONAL CLASSIFICATION}

The Savannah River Site Functional Classification system (as documented in Procedure Manual E7, Procedure 2.25 (Ref. 52)) is a graded approach used to determine necessary and sufficient design, operation, procurement and maintenance requirements for facility structures, systems, and components. There are four Functional Classifications used at SRS:

1. Safety Class (SC)

2. Safety Significant (SS)

3. Production Support (PS)

4. General Services (GS)

The scope of a Facility's Functional Classification is based on the Facility Design Stage, the Authorization Basis for the Facility, and the level of the hazards analysis available. These factors determine the Functional Classification process steps and the "status" (preliminary, interim, or final) of the completed Functional Classification.

The current Functional Classification of the D-Area Heavy Water Facilities is contained in Reference 53, but it does not meet the current Functional Classification procedure (Ref. 52). However, this report has been determined to meet the intent of the Functional Classification procedure, and will not be updated to reflect the current procedure due to the limited life expectancy of the heavy water in D Area. Concerns over the adequacy of the current report have been reviewed and it was determined that the current classifications are correct (Ref. 43). 


\subsection{SAFETY ENVELOPE}

Heavy Water operations in D Area consists of the Rework Unit (RW), DuPont Water (DW) Plant, Moderator Processing Facility (MPF), Technical Purification Facility (TPF), and drum storage facilities. These facilities are used to remove contaminants from the heavy water, purify it to reactor specifications, and store the heavy water until processing and/or transfer to another onsite location. The safety envelope of these facilities is established through the Technical Standards (Ref. 3) and this Basis for Interim Operation (BIO).

The Technical Standards (Ref. 3) and this BIO address the operating restrictions and administrative controls that are necessary for the safe restart and operation of the Heavy Water processing and drum storage facilities. The controls are adhered to through the execution of the safety management programs discussed in Section 3.0 of this BIO.

The controls that are required to maintain the safety analysis for the Heavy Water portion of D Area (Buildings 420-D, 420-2D, 421-D, 421-2D, and 421-4D) include the following:

- 420-D (including 420-2D) curie content

- Freeze protection procedures

- Control of hazardous material

- Control of combustible material

- Control of explosive material

- Radiation monitoring 


\subsection{SAFETY EVALUATION}

The concern over operation of the Heavy Water processing and drum storage facilities in D Area is an accidental release of tritium to the environment. Accidental releases of tritium can result in offsite exposures through either direct airborne release or aqueous release. Therefore, tritium is the only hazardous or radiological material that has the potential to represent any threat of significance to facility personnel or the general public.

Releases of tritium in the Heavy Water facilities may be the result of leaks in the system, normal operation, operator error, accidents (transportation truck accident, fork truck accident, fires, or improper drum handling), or natural phenomena events (NPH) such as high winds, tornadoes, earthquakes, and floods.

The total tritium inventory of Building 420-D (including Building 420-2D) is controlled to less than 270,000 curies. This is maintained by, at a minimum, monthly tritium calculations for the facility and controlled by the Technical Standards (Ref. 3). The 270,000 curie limit | was chosen to minimize the dose to the public from any accidental releases of tritium as well as remaining below the Category 2 limit of 300,000 curies of tritium in DOE-STD1027-92 (Ref. 4). This results in Building 420-D (including Building 420-2D) being placed into a Hazard Category 3 facility categorization (Ref. 5).

The total tritium inventory of Building $421-2 \mathrm{D}$ is greater than 300,000 curies of tritium. This inventory includes the TPF process as well as drum storage. Because the tritium inventory in greater than 300,000 curies and no other radionuclides or hazardous chemicals are in the facility, Building $421-2 \mathrm{D}$ is classified as a Hazard Category 2 based on the guidance in DOE Standard 1027-92 (Ref. 4).

Buildings 421-D and 421-4D contain tritium inventories that are greater than 300,000 curies of tritium. Therefore, based an the tritium content of these buildings and that no other radionuclides or other hazardous chemicals are contained in these buildings, Buildings 421-D and 421-4D are classified as Hazard Category 2 facilities based on the guidance in DOE Standard 1027-92 (Ref. 4).

The buildings covered by this BIO (420-D, 420-2D, 421-D, 421-2D, and 421-4D) are not seismically qualified or hardened to withstand the forces of high winds or tornadoes. Therefore, it is assumed that the buildings fail and result in a maximum release of tritium during the range of NPH events that occur with a frequency of less that $10^{-2}$ per year. This estimate of the frequency range is a qualitative judgment based on the appearance and construction of the facilities. The estimate also takes into account that the lifetime of the heavy water in $D$ Area will be less than five years.

Therefore, in order to determine the source term for an NPH event in D Area the following assumptions were made for the tritium inventory: 
- 300,000 curies is the maximum amount released from DW, RW, MPF and 420-2D during high winds, tornadoes, and earthquakes.

- For the drum storage, all drums of heavy water stacked three high and one half of the drums stacked two high will rupture and spill their contents during high winds, tomadoes, and earthquakes

- It is assumed that drums of heavy water are temporarily stored on transportation trailers in the area prior to the NPH event. This results in the release of a maximum of 255,000 curies of tritium.

- The maximum expected tritium inventory for D Area is given in Reference 43 . which results in a source term of $2,577,500$ curies of tritium released during high winds, tornadoes, and earthquakes. This release is based on 300,000 curies of tritium released from Building 420-D, 255,000 curies of tritium released from drums of heavy water stored on trailers in the area, and one half of the remaining inventory of heavy water in the storage buildings.

The dose to the general public for a spill of 2,577,500 curies of tritium in D Area is an effective dose equivalent (EDE) of 90 mrem (Ref. 41). This value is based on a $2 \%$ evaporation dose in 2 hours and is consistent with other heavy water spills within the EFR Division BIOs and the K-Reactor Safety Analysis Report. The dose calculations also assume worst sector and meteorological conditions that are not exceeded $99.5 \%$ of the time. Because of the close proximity to the site boundary, co-located worker doses have been deleted from this revision to the BIO. Co-located worker doses are calculated based on $50 \%$ meteorological data and would be less than the offsite consequences which use $99.5 \%$ meteorology.

The aqueous release from a high wind, tornado, or earthquake event is evaluated at the U.S. Highway 301 Bridge that is downstream from SRS. The dose corresponding to the postulated release is an EDE of 36 mrem (Ref. 41) for the general public from the aqueous release. This dose is based at the Highway 301 Bridge on a 2,577,500 curie release to the process sewer in D Area, minimum Savannah River flow, and the general public consuming two liters of water per day from the Savannah River.

The dose consequences from leaks in the system, normal operation, operator error, or accidents (transportation truck accident, fork truck accident, fires, or improper drum handling) are bounded by those for the high wind, tornado, or earthquake events.

The D Area facilities housing the heavy water processes and drum storage are approximately 137 feet above sea level (Ref. 43). The maximum historical flow of the Savannah River of 360,000 cubic feet per second (cfs) corresponds to an approximate elevation of 118 feet above the msl at the Vogtle Electric Generation Plant (VEGP) directly across the river from the SRS. The probable maximum flood (PMF) for the 
Savannah River where Upper Three Runs Creek enters the river is approximately $1,001,000$ cfs. This information is based upon Appendix B to the Nuclear Regulatory Commission (NRC) Regulatory Guide 1.59 at the VEGP opposite the SRS, and precludes consideration of the domino-type failure of upstream dams. The calculated PMF water level is 138.5 feet. The water level for the Savannah River was conservatively determined by the US Army Corp. of Engineers' HEC-2 computer program. The inclusion of a domino type failure of the dams that are up river from the Savannah River Site would lead to a peak flood elevation at VEGP of 141 feet above msl (Ref. 61).

Because D Area is below the PMF level, it will be assumed that the heavy water processing and storage facilities are damaged enough to release as much tritium during a flood as during high winds, tornadoes, or earthquake events. In this scenario the amount of tritium released to the Savannah River is the same as the high wind, tornado, and earthquake events but the flow of the Savannah River is much higher. This leads to lower liquid doses at the Highway 301 Bridge based on a simple dilution model, where complete mixing is assumed to occur, for which flow studies have shown to closely approximate actual conditions in the Savannah River. Thus, doses at a particular receptor point downriver are inversely proportional to the river flow rate. Therefore, the consequences from this release are bounded by the aqueous release from high winds, tornadoes, and earthquakes because those aqueous releases assume a minimum Savannah River flow which will be greatly exceeded during flooding conditions. 


\subsection{CONCLUSION}

The RW, DW, and MPF processes in Building 420-D (including 420-2D) and the TPF process in Building 421-2D will be used to purify the remaining inventory of heavy water at SRS while Buildings 421-D, 421-2D, and 421-4D will be used to store drums of heavy water until removal to another location. This mission of purification and removal to another location is expected to take up to five years to complete. The potential hazard associated with heavy water processing and drum storage in D Area is an accidental release of tritium.

The Heavy Water processing facilities contained in Building 420-D (RW, DW, and MPF). including the drum charging and drawoff building (420-2D) are classified as a Hazard Category 3 facility as defined by DOE-STD-1027-92 (Ref. 4). This classification is the result of controlling the tritium inventory to below 300,000 curies (Ref. 3). Building 421$2 \mathrm{D}$ is classified as a Hazard Category 2 facility because the tritium inventory in the facility is greater than 300,000 curies. This facility includes TPF and a drum storage section. The remaining facilities covered by this BIO are used for drum storage and include Buildings 421-D and 421-4D. These buildings are classified as Hazard Category 2 facilities because their tritium content is above the Hazard Category 2 threshold limit for tritium of 300,000 curies.

The release of tritium during postulated NPH events results in an EDE received by the general public of 90 mrem (Ref. 41). The consequences from this accidental release of tritium places the facility into the moderate consequence category for radiological accidents (Ref. 42). The aqueous release from a postulated accident in D Area results in a liquid dose of $36 \mathrm{mrem}$ at the Highway 301 Bridge. Based on these dose consequences the scenario class for the postulated accidents were determined to be Class III -i.e., termed "marginal" by the BIO guidance document (Ref. 42). This is based on the fact that the event scenarios leading to a release of tritium are less than $10^{-2}$ per year and the offsite doses for these events are less than 100 mrem at the site boundary.

The facility worker is protected through the adherence to both WSRC and EFR Division level procedures covering areas such as waste minimization, radiation protection, personnel safety, and conduct of operations.

The impact of normal operation and postulated accident scenarios on the facility worker and general public is insignificant.

The approved BIO and Technical Standards (Ref. 3) represent the authorization basis for the Heavy Water processing and drum storage facilities. 


\subsection{REFERENCES}

1. "Technical Safety Requirements," DOE Order 5480.22, U.S. Department of Energy, Washington, DC, February 25, 1992.

2. "Nuclear Safety Analysis Reports," DOE Order 5480.23, U.S. Department of Energy, Washington, DC, April 30, 1992.

3. "400 AREA HEAVY WATER TECHINICAL STANDARDS,". DPSTS-400.

4. "Hazard Classification and Accident Analysis Techniques for Compliance with DOE Order 5480.23, "Nuclear Safety analysis Reports," DOE Standard DOE-STD-102792, U.S. Department of Energy, Washington, DC, December 1992.

5. Wellmaker, K.A., "HAZARD ASSESSMENT DOCUMENT FOR BUILDING 420D (U)," WSRC-TR-94-026, Rev. 0, February, 1994.

6. DELETED.

7. Nuclear Facility Unreviewed Safety Questions, WSRC Procedure Manual 11Q, Procedure 1.05, Westinghouse Savannah River Company, Aiken, SC.

8. Heavy Water Processing Facility Distillation System, System Description, RWOIBA01, Rev. 0.

9. Technical Purification Facility, System Description, RWMIBA01-SD, Rev. 0.

10. Savannah River Site Environmental Monitoring Plan, WSRC-3Q1-2, Volume 1, Section 1000 Addendum, Westinghouse Savannah River Company, Aiken, SC.

11. Management Policy 4.4, "Radiation Protection," WSRC Policy Manual 1-01, Westinghouse Savannah River Company, Aiken, SC.

12. Administrative \& Procedure Controls System for Reactor and Nonreactor Facilities, WSRC Procedure Manual 11Q, Westinghouse Savannah River Company, Aiken, SC.

13. Savannah River Site ALARA Guide, WSRC-IM-90-140, Westinghouse Savannah River Company, Aiken, SC, December 14, 1990.

14. DOE Order 5480.11, Change 3, "Radiation Protection for Occupational Workers," U.S. Department of Energy, Washington, DC, June 17, 1992.

15. Health Protection Department Administrative Procedure Manual, Procedure Manual Q1-1, Westinghouse Savannah River Company, Aiken, SC. 
16. Savannah River Site External Dosimetry Technical Basis Manual, WSRC-DM-92101, Westinghouse Savannah River Company, Aiken, SC.

17. Radiological Controls, WSRC Procedure Manual 5Q, Westinghouse Savannah River | Company, Aiken, SC.

18. Internal Dosimetry Technical Basis Manual (U) WSRC-IM-90-139, Rev: 1 , Westinghouse Savannah River Company, Aiken, SC.

19. Reactor Restart Division Administrative Manual-Procedures, WSRC Procedure Manual RD 7.1, Westinghouse Savannah River Company, Aiken, SC.

20. "Writers Guide For Normal Operating Procedures," WSRC-IM-90-136.

21. DELETED.

22. Quality Assurance Manual, WSRC Procedure Manual 1Q, Westinghouse Savannah River Company, Aiken, SC.

23. DOE Order 5480.18, "Accreditation of Performance-Based Training for Category A Reactors and Nuclear Facilities," U.S. Department of Energy, Washington, DC, November 2, 1989.

24. DOE Order 5480.6, "Safety of Department of Energy-Owned Nuclear Reactors," U.S. Department of Energy, Washington, DC, September 23, 1986.

25. ANSU/ANS 3.1-1981, American National Standards Institute/American Nuclear Society.

26. "TMI Action Plan," NUREG-0737, U.S. Nuclear Regulatory Commission, Washington, DC.

27. DOE Order 5480.20A, "Personnel Selection, Qualification, Training, and Staffing Requirements at DOE Reactor and Non-Reactor Nuclear Facilities," U.S. Department of Energy, Washington, DC, November 15, 1994.

28. D Area Technical Purification Facility (TPF) (Mercury Removal Process) Rework (RW) DuPont Water (DW) Startup Plan, WSRC-TR-93-043, Rev 0.

29. Startup Test Manual, WSRC Procedure Manual 5E, Westinghouse Savannah River Company, Aiken, SC.

30. SRS Conduct of Operations, WSRC Procedure Manual 2S, Westinghouse Savannah River Company, Aiken, SC. 
31. WSRC Employee Safety Manual, WSRC Procedure Manual 8Q, Westinghouse Savannah River Company, Aiken, SC.

32. DOE Order 5000.3B, "Occurrence Reporting and Processing of Operations Information," U.S. Department of Energy, Washington, DC, January 19, 1993.

33. Site Item Reportability and Issues Management, WSRC Procedure Manual 9B, Westinghouse Savannah River Company, Aiken, SC.

34. WSRC Management Requirements and Procedures, WSRC Procedure Manual 1B, Westinghouse Savannah River Company, Aiken, SC.

35. "400-D Area Conduct of Operations Assessment/Final Report," RRD-RES-930128, May 27, 1993.

36. WSRC Policy Manual, WSRC-1-01, Westinghouse Savannah River Company, Aiken, SC.

37. WSRC Quality Assurance Management Plan, WSRC-RP-92-225, Westinghouse Savannah River Company, Aiken, SC.

38. DELETED.

39. SRS Emergency Plan, WSRC Procedure Manual 6Q, Westinghouse Savannah River Company, Aiken, SC.

40. Fire Protection, WSRC Procedure Manual RD 4.1, Westinghouse Savannah River Company, Aiken, SC.

41. Rabin, S.B., "Dose Analysis for D Area Release (U)," S-CLC-D-00006, Rev. 2, Westinghouse Savannah River Company, Aiken, SC, December, 1995.

42. Guidance for Preparation of DOE 5480.22 (TSR) and DOE Order 5480.23 Implementation Plans, DOE-STD-3011-94, U.S. Department of Energy, Washington, DC, November, 1994.

43. Bohrer, S.R., "Updated D Area Drum Tritium Inventory Data, Rev. 1 (U),." EFRENG-95-0055, October 19, 1995.

44. Maintenance Administrative Procedures, WSRC Procedure Manual IY, Westinghouse Savannah River Company, Aiken, SC.

45. Health and Safety Manual for Hazardous Waste Operations, WSRC Procedure Manual 20Q, Westinghouse Savannah River Company, Aiken, SC. 
46. Industrial Hygiene, WSRC Procedure Manual $4 Q$, Westinghouse Savannah River Company, Aiken, SC.

47. D Area Fire Control Preplan, WSRC Procedure Manual 2Q2-4-D, Westinghouse Savannah River Company.

48. Fire Protection Program Manual, WSRC Procedure Manual 2Q, Westinghouse Savannah River Company, Aiken, SC.

49. "Unreviewed Safety Question," DOE Order 5480.21, U. S. Department of Energy, Washington, DC, December 21, 1991.

50. WSRC Configuration Management Control, Procedure Manual 7E.

51. WSRC Engineering and Engineered Services Procedures Manual, Procedure Manual IE.

52. SRS, Conduct of Engineering and Technical Support, WSRC Procedure Manual E7, Westinghouse Savannah River Company, Aiken, SC.

53. Uniform Listing of Heavy Water Facility Systems, Acronyms, and Functional Classification, WSRC-TR-90-42-055, Rev. 0, September, 1993.

54. Fire Hazards Analysis for 420-D, F-FHA-D-00003, Rev. 0, June 29, 1994.

55. Fire Hazards Analysis for 421-D, F-FHA-D-00002, Rev. 0, May 18, 1994.

56. Emergency Management Hazards Assessment for D-Area Facilities, WSRC-TR-940102, Westinghouse Savannah River Company, Aiken, SC, July 22, 1994.

57. "Fire Protection Flame/Spark Permits for Cutting, Welding, and Grinding Accidents," DMP 4.04, Westinghouse Savannah River Company, Aiken, SC.

58. Health Protection Department Radiation Survey Procedure, WSRC Procedures Manual 5Q1.2, Westinghouse Savannah River Company, Aiken, SC.

59. Instrument Calibration Procedure, RC\&HP Procedure Manual Q2, Westinghouse Savannah River Company, Aiken, SC.

60. Respiratory Protection Program Procedure, WSRC Procedure Manual 4Q1.6, Westinghouse Savannah River Company, Aiken, SC. 
WSRC-TR-94-0158, Rev. 2

61. Savannah River Site Production Reactor Safety Analysis Report, K Production Reactor, WSRC-SA-10003, Amendment 4, Westinghouse Savannah River Company, Savannah River Site, Aiken, SC, November 8, 1992.

62. K-Reactor Cold Standby Basis For Interim Operation (BIO) (U), WSRC-TR-94-. 207, Rev. 0, Westinghouse Savannah River Company, Aiken, SC, February, 1995.

63. Schwallie, A. L., "DOE Orders 5480.22 and 5480.23, Compliance Assessment and Implementation Report Revisions (U)," ESH-DMS-950317, Westinghouse Savannah River Company, Aiken, SC September 27, 1995.

64. Moderator Processing Facility, Facility Description, RWOIBH09.SD, Rev. 0, Westinghouse Savannah River Company, Aiken, SC.

65. EFR Division Procedure RDP14.01, "Reactor Division Chemical Management Program," Westinghouse Savannah River Company, Aiken, SC.

46 